\title{
Education in Information Society: a Trend to Virtualization
}

\author{
Irina G. Borisenko* \\ Siberian Federal University \\ 79 Svobodny, Krasnoyarsk, 660041, Russia
}

Received 14.11.2014, received in revised form 29.01.2015, accepted 14.04.2015

\begin{abstract}
This article analyzes the trends resulting from the processes of informatization, their ambiguity in the course of transition to the information society. The author emphasizes that informatization of education leads to radical changes in the education system. These changes are accompanied by changes in traditional methods of getting knowledge at the university. The article, in particular, shows that ambivalent trends, characterizing the processes of informatization in the educational system, often lead to virtualization of social relations.

To understand the nature of the educational virtualization process in a global world it is vital to take into account that the educational system is defined as a set of factors determining a personality's learning and development, socio-cultural and economic conditions of the society that effect education, character of information and interpersonal relations, and interaction with social environment. The dependence of interpersonal relations and interaction of education with the social environment is obvious. It means that in any case factors and conditions, determining a personality's learning and development, are not only introduced from the socio-economic environment which is external in relation to education, but are also the product of information-and-educational interaction, interpersonal relations of the subjects of education.

Virtualization of modern educational processes is largely connected with the fact that the informational nature of the education system creates preconditions for universalization of tools and resources of interdisciplinary links. Various humanitarian and natural-science subjects integrate through the global educational environment. This implies a search for the sources of interdisciplinary links and means of their implementation, using authors' tools, methods and forms. This process is aimed at the formation of the students' systematic scientific thinking, ecological and information culture, creative activity and high morals. These qualities result in successful adaptation, life and work in the global information society.

Virtualization of educational space changes the teacher's role. However, it does not deny the importance of the traditional subject-object relations in the educational process.

In this respect smart technologies play a special role. Despite a trend towards virtualization, modern educational space is based not only on the latest information technologies, but also on the use of traditional authors' educational techniques. Due to a proper combination of traditional and information approaches the educational process remains effective.
\end{abstract}

Keywords: information society, information education, global education, educational issues, information, computer science.

Research area: philosophy.

(C) Siberian Federal University. All rights reserved

* Corresponding author E-mail address: i.g.borisenko@yandex.ru 
Actualization of educational issues in modern society is determined by virtualization processes, in particular, which increasingly manifest themselves in education due to information technologies. Nowadays information is playing an increasingly important role in society and especially in science owing to an intensive deployment of informatization process and global information society formation. The concept of information has come to the forefront in modern science and become a general scientific category. At the same time expansion and fundamentalization of a categorial status of information makes it possible to consider a number of issues, including that of virtualization of education.

Dissatisfaction with the existing educational reality is characteristic to all times and societies. It is one of the sources to improve educational techniques and correct educational practices content. However, it did not always grow into expectations of deep institutional changes or demands to completely abandon the traditional educational institutions the way it is experienced nowadays (Sud nad sistemoi... 1991). The work of modern educational institutions is largely influenced by hard conditions of market competition which objectively contribute to educational content dehumanization. In addition, modern systems of education function in a fairly liberal information environment where interactively functioning media become the main source of influence (Kolin, 1995, 1996).

Transition to the society of knowledge as to a stage of information society development is connected with the fact that knowledge or information retain personally significant, individualizing characteristics to a lesser extent and are increasingly gaining economic importance in the context of globalization (Chernykh 2012). The solution of the problem of crisis in education is inseparably connected with the solution of the problem of modern sociality crisis at different levels of its functioning. The research faces the challenge to formulate such principles of education functioning in modern transforming society which will contribute to overcoming the crisis of education itself, on the one hand, and to weakening of fundamental contradictions of modern society, on the other hand.

B.S. Gershunskii's work came into a greater prominence in the national philosophy of education (Gershunskii, 1997). He analyzes education as an institutional tool to save and shape the features of mentality which is essential in the conditions of today's global problems. The key trends of the world and western education systems development are given a detailed consideration in B.L. Vul'fson's and A.N. Dzhurinskii's works (Dzhurinskii, 1999; Vul'fson, 1999).

The vast majority of modern problems of information society formation is complex and requires an interdisciplinary approach to their analysis, originating at the level of a certain higher education institution or other educational institution. This naturally raises the need for a more thorough investigation of the role of information in shaping new models of education, in particular. At the same time achieving a high level of e-learning is possible under the condition of a harmonious transition from paper to electronic content, the latter guaranteeing the greatest efficiency of the knowledge transfer.

The need for a new information model of education is determined by the revolutionary transformations in the form of reframing the education itself. A new paradigm, focused on a new triad "knowledge-comprehension-skills" development, sets new challenges to the teachers since an old triad "knowledge-abilities-skills" does not meet the needs of the information society. In this context one might talk about educational revolution which is closely related to futurology 
(E. Toffler 2002; O. Toffler 2010) in the context of sustainable development, in particular.

Many researchers in the field of philosophy of technology draw attention to the fact that technology becomes a human's medium. According to Ellul', "technology surrounds us as a solid cocoon without a bright spot, making nature (according to our first direct estimation) completely useless, submissive, secondary, and unimportant ... The decisive factor here is filling our thoughts as well as our sensuality with mechanical processes. It is technology that is now the "reality" without any definitions. There is no need either in senses or in values here. It imposes itself just because it exists" (Ellul', 1986).

The conception of advance education is one of the most influential philosophical-educational conceptions in domestic global studies nowadays. The term "advance education" is widespread in specialized literature. The conferences on advance education are held, collections of papers are published. Thus, the concept finds its adherents. It is appropriate to say that the conception of advance education is still under development (Ursul, 2001). A.D. Ursul's conception of advance education includes a synergistic picture of social dynamics where any equilibrium steady state of the social system, in the end, exhausts its potential stability and enters an unstable state with uncertain prospects under the pressure of accumulated changes. A.D. Ursul's conception of advance education is a continuation of "V.I. Vernadsky's line" in domestic global studies. It is one of the first attempts to comprehend a possible mechanism of functioning of the world system of education when the growing risks of human activity are taken into account. According to A.D. Ursul, the system of global education should be the system of advance education, the system which will constantly adjust its content in compliance with reliable forecast data on the most probable threats to global community and thereby contribute to prevention of global socio-natural disasters. A.D. Ursul calls a necessary source of forecast data "the noosphere intelligence". It implies artificial intelligence which is nonexisting yet and able to quickly process the entire system of knowledge accumulated in the world. The conception of advance education is based on the reasoning of use of education, closely integrated with science, as an information mechanism of "advance reflection" for modern civilization. Largely basing on V.I. Vernadsky's and N.N. Moiseev's ideas, reports to Rome club and conception of sustainable development of civilization, A.D. Ursul offers to organizationally subordinate the educational system to a certain centre of social forecasting and planning. According to him, forecasting data will make it possible to actualize knowledge, values and patterns of behavior, which are the most demanded ones in the short term, by means of specific educational actions and, thereby, gently guide a global social system along the safe path of development.

The purpose of this process is the formation of students' systematic scientific thinking, ecological and information culture, creative activity and high moral qualities, which are the qualities leading to successful adaptation, life and work in global information society. Thus, in his article "Information culture and quality of life in the information society" K.K. Kolin notes that the content of modern education system is not focused on an individual's preparation for life in modern information society, that "the education system is not targeted at the formation of new information and electronic culture, human and society, adequate to that new information reality which surrounds each person nowadays and changes his / her way of life, many values, habitual patterns of behavior" (Kolin, 2010a).

Virtualization of educational space brings changes to the teacher's role. However, it does 
not deny the importance of traditional subjectobject relations in the educational process. It should be noted that the paces of technical progress force the teachers to constantly update their professional knowledge, master and use new technologies, improve their computer literacy and information culture because there is a need for constant updating of information sources. In this regard it is important to note that globalization "....arose from an avalanche propagation of the world market and information. At the same time it generates an enormous gap in living standards and plans of the developed and less developed countries" (Iatsenko, 2013).

Another important aspect, effecting virtualization processes in modern educational process, is due to the fact that the information model of education is closely linked with axiological aspects. This model makes it possible to define the prospects of a certain education system in the near future. In this case the level of education is the level of not just an individual's preparation for future conscious activity, but also of the formation of a pattern of new relations in any educational establishment where information is of the first priority. It is not coincidentally that similar trends are tracked at the highest level. Thus, according to the UNECE strategy, one of the important areas in the education system is "acquiring the knowledge by the teachers that enables them to include sustainable development issues in teaching their subjects" (Proekt Strategii... 2004).

Information model of education presupposes close interaction with science. It is implemented in the form of sustainable development and implies normative predictions. According to our survey, a more certain focus of science on the future starts with education, which gives the opportunity to avoid "the shock of the future" (E. Toffler, 2002).

Analyzing the information model of education, Kh.V. Zakiev shows the ways of human potential realization through the use of information, when "education, in the end, opens up the prospect of mankind's existence in the age when any person, sitting in front of a computer screen in the lab, office or public library, can view a huge amount of information stored in different data bases" (Sokiev, 2013). All this suggests a certain level of proficiency in information technologies.

Despite a variety of positions a common thing for all researchers, studying modern information society, is recognition of new information technologies, information diversity and pluralism (this can be a sign of postmodernism) and new distribution of information for the benefit of society. The key features of a new information model of education to some extent have been the subject of such world's leading researchers as E. Toffler, F. Fukuyama, F. Hayek, M. Castells (Castells, 2004), studying the issue of social institutions formation in the information society. Their contribution is in the research of key characteristics of all elements of the information society, including education. Besides, these researchers revealed the features of the information and knowledge relationship, being essential for understanding the teacher's new role in modern educational process.

Information activity currently plays a key role in functioning of any social system as a whole that gives it a special status among various forms of a human's life support and his / her social nature (Il'inskiy, 2002; Illich, 2006).

From a socio-philosophical point of view the society informatization should be considered a global civilizational process having a significant impact on almost all areas of human life and society nowadays. In the future it will largely determine the whole image of a global information society, a new civilization of the XXI century that has a fundamental effect on the educational sphere (Ursul, 1996). 
The teacher nowadays should have an idea about information as one of the fundamental concepts, on which modern scientific picture of the world is a based, and new information and communication technologies for effective implementation of all information processes. In addition, he /she must have a developed informational and operational thinking aimed at selecting the required information in a certain problem situation and making optimal decisions to solve it, as well as at life skills in the information society, understanding a special role of information and information processes in the development of the society (Mashchenko, 2011).

Informational nature of modern educational system is one of its most important features. In the age of global informatization its recognition is necessary for comprehension and research of the content of educational environment and its practical use, transformation, development of education as well as the development of educational methodology and its goals in presentday conditions (Robert, 2010).

A vast majority of contemporary issues related to the information society development are complex and require interdisciplinary approach to their analysis, the latter originating at the level of a certain higher education institution or other educational institution. In this regard there is a natural need for a more thorough research of the role of information in shaping new models of education, in particular.

In our opinion, despite all the methodological gimmicks, determined by new technological means, the traditional subject-object scheme in the educational process will retain its position in the coming decades. The role of information in this process is difficult to overestimate (Fukuyama, 1992; Hayek, 2005; Shvartsman, 1989).

Another important aspect of the issue of educational institutions and informatization interaction is in the following: the global communicative space defeats all attempts to build the "iron curtain" their purpose, thus, the states must be ready to defend the system of their values and way of life not with a mere ban but with more effective methods of informational impact. Actualization of the problems, connected with designing a new model of education, depends on the specific features of the education system as a form of social consciousness.

The value of information in education is determined by its dualistic nature. It prepares young people for the future but it is based on our ancestors' experience. It can be emphasized that conservative and liberal ideas are side by side here and often in conflict.

In modern conditions a mechanism, guaranteeing the interaction of educational institutions with the conceptions of the information society which would guarantee the optimum focus on an individual's development in the curriculum, is extremely essential. Nowadays the demands of practice go ahead of cognitive abilities, and we cannot exclude emergence of such a situation when the society, which is generally able to cognize any natural phenomena and transform them to states necessary for the production of life resources, will simply lack enough time before global technological crisis (Goriunov, 2012). However, it is important to focus not only on the anthropological factor but also on the potential threats caused by civilization to the earth's biosphere.

In the modern world, ambiguous for civilization and global education, the functions of adequate response to modern changes and even their short-term anticipation, protection from threats and dangers come in the foreground in education. Information-and-translational function of education moves away to its periphery while a constructive-and-creative, innovative-andeducational basis, facilitating decision-making on crisis management and survival, is prioritized. 
The focus shifts from the sphere of knowledge acquisition to that of developing, creative and advanced thinking, the sphere of educational research creativity which implies mastering the methods of decision making and crisis simulation and training. Educational systems of many countries are currently undergoing a new phase of their radical modernization. Its aim is to significantly improve the quality of education, develop modern scientific worldview and an individual's new information culture. Philosophy of information has been developing in Russia for over fifty years and plays an increasingly important role in science owing to an intensive deployment of informatization process and formation of global information society.

New high information and communication technologies, electronic services, social networks, and the Internet are increasingly getting global, covering all the spheres of society. Information and communication unity and human civilization diversity are developing. Informatization means make the access to different information resources available for every person. Electronic communication development involves democratization and liberalization of the society. Freedom to receive and disseminate information is not only a social good but also means of individual development. New technologies change a human's consciousness, his / her worldview (Borodina, 2012).

A full study of specific features of virtualization of education implies sociophilosophical analysis of the role of information in the modern world that depends on the solution of social problems, in general, and education as the most important social institution, in particular. This means that any actions on information measuring and especially its limitation should agree with an educational aspect of problems since the education system is always both a cause and a consequence of social transformations.
Introduction of new information technologies in education accelerates transformation of the entire education system. The lag of philosophical and theoretical comprehension of the problems of education from the rapidly developing information technologies largely determines the problems of information education which are vital to overcome for the educational system of the information society to be developed. Thus, in particular, the problem of information in contemporary education becomes significantly acute in the context of selecting the information source (between a traditional textbook and an electronic textbook). It is known that the degree of usefulness and harm of the latter is a subject of debates even on the level of medicine and psychology, not to mention traditional teaching environment. In our opinion, a traditional textbook has some advantages. Thus, in particular, a perfect e-book will not replace a specific epistemological situation resulting from the contact with a traditional textbook.

Information process in education is the most important communications determiner, and the use of modern information technologies is an objective necessity for the educational system's sustainability in a global world. At the same time, the optimal functioning of education implies appropriate information mechanisms, and the change of social guidelines requires their adjustment in the appropriate direction, i.e. casting-off the features which are indistinctive for a certain society and, consequently, its educational sphere.

Contemporary education, based on the latest information technologies, sets a corresponding impulse not only to some population groups but to whole countries that have managed to maintain priority in the education sector due to the efficient combination of traditional and new information technologies. 
The educational phase of modern information revolution has several distinctive characteristics, among which virtualization processes are worth highlighting. This is due to the fact that the learning process cannot be regarded as accumulation of information exclusively as, according to the laws of dialectics, quantitative parameters of information educational space involve the emergence of qualitative changes sooner or later. It is information that confirms inviolability of the principle of educational processes continuity to the maximum extent. Concern about the information quality in an educational institution is also the process of saving educational traditions and the attempt to avoid a negative impact of virtual trends. Moreover, the need for modern approaches to the issues of the educational systems development is actualized in the light of global trends. This makes it possible to present information as a basis for the formation of an educational institution's educational base.

Informational nature of contemporary educational system is one of its most important properties. In the age of global informatization recognition of this property is necessary for understanding and research of the content of educational environment and for practical use, transformation, and development of educational sphere as well as the development of educational methodology and achievement of its goals in modern conditions. Education, using new information technologies, should become the core of the information society and one of the priority mechanisms for further development. And this, however, means greater attention to all information aspects of an educational process (Ursul, 2010).

Modern aspect of informatization of education is closely connected with the definition of informatization of society as a means of transition to a state of an information society. Informatization is a "systemic-and-activity process of acquiring information as a resource of management and development by using IT tools to create information society and further continuation of civilization progress on this basis" (Ursul 1993). Based on this definition, it can be emphasized that informatization of education is a means of development, modernization, and improvement of the entire educational system corresponding to an information society.

Fundamental researches of this problem, carried out in the seventies of the last century by academician A.D. Ursul (A.D. Ursul, 1997, 1998; A.D. Ursul, A.D. Ursul, 2013), are getting their higher relevance as philosophical problems of information are currently increasingly discussed in the scientific world. This issue has become not only an interdisciplinary and general science one but global and even cosmic. This is evidenced by modern approaches to the analysis of the issues of cosmology and other sciences about space (Ursul, 2007) as well as quantum mechanics, general physiology, genetics and psychology. This quite broad understanding of information serves the grounds to consider the science of information - computer science - to be one of the most fundamental sciences. At the same time expansion and fundamentalization of a categorial status of information results in a new focus of considering a number of issues, including:

- the study of a conceptual nature of information as one of manifestations of the reality of the world around us;

- a more complete comprehension of the role of information in evolutionary processes in physical and biological systems as well as in human society and education being an important form of the latter.

In the last decade computer science as a fundamental science is turning into a key component of the entire system of scientific knowledge and will largely determine the ways towards a global information society based on 
knowledge. Therefore, a heightened interest to the issue of finding the place of computer science in the system of sciences as well as to its basic principles and historical and philosophical aspects, which are currently observed in the sphere of science and education, are quite clear (Kolin 2010b).

The term "information-and-educational environment" nominates a new entity of integration of educational and informational environments. The literature review has showed that it is interpreted as:

1) a systemically organized informational, educational and hardware, inseparably connected with a human as a subject of educational space;

2) a single information-and-educational environment built with the help of integration of the information in traditional and electronic media, computer and telecommunication technologies of collaboration, including virtual libraries, distributed databases, educational-andmethodical packages and expanded didactical means;

3) a set of interrelated subsystems purposefully providing pedagogical process (e.g., informational, technical, didactical, methodical), etc.

Modern educational processes cannot take place without including a wide range of information resources and development of processing and presenting information skills in learning. Information environment, created on the basis of high-tech means of information, is seen as an integral part of learning environment. Most researchers consider the information-andeducational environment within the frame of improvement of didactic theory and practice as applied to new social and economic conditions. They describe a model of a pedagogical process, in which innovative technologies potential is implemented. This leads to effective organization of individual and collective work of a teacher and the students as well as integration of various forms and strategies of mastering an academic discipline, which are aimed at developing the students' purposeful autonomous cognitive activity. In particular, L.S. Vygotsky and his followers regarded learning as an active process in which the learner plays the role of knowledge "designer" and the process of "designing" knowledge is based on his / her current and past knowledge (Vygotsky, 1991). According to this view, learning in the information-andeducational environment is an active process aimed at extracting, constructing knowledge but not its mere reproduction. Learning in this interpretation fulfills the role of support of a student's constructive efforts put towards gaining knowledge and mastering skills and abilities autonomously (Andreev, 2000).

The need for new approaches to the issue of virtualization of education is also determined by a huge flow of information which is increasing exponentially. This leads to ignoring the classical subject-object system in education. Nevertheless, the teachers' role is getting more significant. They perform an essential function while effectively assisting the students in systematization of information and development of original techniques contributing to their adaptation in modern information flows. That is why the efficiency of the education process depends not only on the teacher's professional level and his / her ability to assimilate innovations. It is important that the teacher "... must become a central figure of the coming era, information and scientific knowledge being his / her main weapon and IT means and information technologies being his / her main tool" (Kolin, 1997).

Virtualization of modern educational processes is largely connected with the fact that the informational nature of the education system 
creates preconditions for universalization of tools and resources of interdisciplinary links. Differentiation in modern education presupposes integration of many academic disciplines through the implementation of intersystem links. Various humanitarian and natural-science subjects integrate through global educational environment. This implies a search for the sources of interdisciplinary links and means of their implementation, using authors' tools, techniques and forms.

New information model of education can and should be considered as a model for the development of social relations, formation of which in the students' environment is largely dependent on electronic media. At the same time this approach increases the threat of literal technocratic approach to the study of the main ways of social flow of information, especially at the stage of knowledge transfer. Any teacher should be aware of his / her role in preparing not just informed generation but also in the formation of the conscious youth interlayer, capable of not only finding the right information but also having immunity to alien information influence. In this regard it can be argued that the main feature of a promising information model of education is not a new communication system but formation of a conscious information-and-knowledge interlayer of the students. In this context it is important to emphasize that the attempts to oppose technical and humanitarian sides of a promising information model of education is at risk of not just splitting a learner's personality but also of his / her identity. That is why many teachers are against information which can be available in education in automatic mode. However, in our view, automation of information flows in the educational process is quite acceptable if control-and-measuring tools are involved (Borisenko, 2014).

Information model of contemporary education naturally integrates all the best practices of individual educators and conceptual provisions of regulatory documents. Its effectiveness is in accumulation of positive practice of "progressive innovation favouring the education system maintenance and development" (Vazina, Kopeikina, 1999). It is quite natural that the task of reorientation of a new information model of education is closely linked with the development of non-traditional forms, types or models of the educational process. It is exactly the way on which there is a possibility to avoid the worst consequences of virtualization of contemporary education and naturally integrate the advantages of traditional and information technologies with the aim of increasing its effectiveness.

\section{References}

1. Andreev A.A. Teoretiko-metodicheskii podkhod $\mathrm{k}$ proektirovaniiu i realizatsii setevogo obrazovaniia [Theoretical and methodological approach to the design and implementation of network education]. Internet-tekhnologii v otkrytom obrazovanii. Materialy seminara (Internet technologies in open education. Workshop materials. Moscow: MESI, 2000. Pp. 12-14.

2. Borisenko I.G. Formirovanie kompetentnosti budushchego kvalifitsirovannogo spetsialista i bakalavra cherez organizatsiiu uchebnogo protsessa $\mathrm{v}$ interaktivnoi elektronnoi obuchaiushchei srede [Formation of a future qualified specialist's and a bachelor's competence through organization of the learning process in an interactive e-learning environment]. Professional'noe obrazovanie $i$ zaniatost' molodezhi: XXI vek. Sistema professional'nogo obrazovaniia v usloviiakh modernizatsii: Materialy Vserossiiskoi nauchno-prakticheskoi konferentsii (Kemerovo, $19-20$ marta 2014 g.: $v 2$ ch. Ch. 1 [Professional education and employment of the youth: XXI century. The system of 
professional education in the conditions of modernization: Proceedings of All-Russian scientific and practical conference (Kemerovo, March 19-20, 2014): in 2 vol. Vol. 1). Kemerovo: GOU "KRIRPO", 2014.

3. Borodina N.A. Sotsial'no-filosofskii analiz informatizatsii obrazovaniia: avtoreferat dis. ... kandidata filosofskikh nauk: 09.00.11 [Socio-philosophical analysis of informatization of education: author's abstract of candidate thesis in philosophy: 09.00.11. Rostov-on-Don, 2012. 28 p.

4. Castells M. Galaktika Internet: Razmyshleniia ob Internete, biznese i obshchestve [The Internet galaxy: Reflections on the Internet, business and society]. Translated from English. Ekaterinburg: U-Faktoriia (with the participation of the Humanitarian University), 2004. 328 p.

5. Chernykh S.I. Izmenenie obrazovatel'nogo prostranstva $v$ informatsionnuiu epokhu: sotsial'no-filosofskii analiz: avtoreferat dis. ... doktora filosofskikh nauk: 09.01.11 [Changing the educational space in the information age: social and philosophical analysis: author's abstract of dissertation ... of doctor of philosophy: 09.00.11]. Novosibirsk: Novosibirsk State Technical University, 2012. $28 \mathrm{p}$.

6. Gershunskii B.S. Filosofiia obrazovaniia dlia XXI veka (V poiskakh praktiko-orientirovannykh obrazovatel'nykh kontseptsii) [Philosophy of education for the XXI century (In search for practically oriented conceptions)]. Moscow: Russian Academy of Education, 1997. 697 p.

7. Goriunov V.P. (2012). Obektivnye osnovaniia sindroma kontsa istorii [Objective basis of the end of history syndrome]. The scientific opinion, (10), 9-20.

8. Dzhurinskii A.N. Razvitie obrazovaniia v sovremennom mire [Development of education in the modern world]. Moscow: VLADOS, 1999. 200 p.

9. Ellul' Zh. Drugaia revoliutsiia [Another revolution]. Novaia tekhnokraticheskaia volna na Zapade (New technocratic wave in the West). Moscow, 1986.

10. Fukuyama F. The end of history and the last man. Free Press, 1992. 418 p.

11. Hayek F.A. von. The Road to Serfdom. The Institute of Economic Affairs, 2005.

12. Iatsenko M.P. (2013). Globalizatsionnye tendentsii kak resul'tat transformatsii istoricheskogo protsessa [Globalization trends as a result of a historical process transformation]. Sbornik nauchnykh trudov SWorld. Vypusk 2. Tom 25 (Collection of scientific works SWorld. Issue 2. Volume 25). Odessa: KUPRIENKO, 2013. P. 46.

13. Il'inskiy I.M. Obrazovatel'naia revoliutsiia [Educational revolution]. Moscow, 2002. 592 p.

14. Illich I. Osvobozhdenie ot shkol. Proportsional'nost' $i$ sovremennyi mir [Liberation from schools. Proportionality and modern world]. Moscow: Prosveshchenie, 2006. 160 p.

15. Kolin K.K. (1995). Informatsionnye tekhnologii - katalizator protsessa razvitiia sovremennogo obshchestva [Information technologis as a modern society development catalyst]. Information technologies, (1), 2-8.

16. Kolin K.K. (1996). Operezhaiushchee obrazovanie i problemy informatiki [Advanced education and problems of computer science]. International cooperation, (2), 6-9.

17. Kolin K.K. (1997). Informatsionnoe obshchestvo i problemy obrazovaniia [Information society and problems of education]. Information society, (2-3), 18-20.

18. Kolin K.K. (2010a). Informatsionnaia kul'tura i kachestvo zhizni $v$ informatsionnom obshchestve [Information culture and quality of life in the information society]. Otkrytoe obrazovanie, (6), 84-89. 
19. Kolin K.K. (2010b). Filosofiia informatsii i fundamental'nye problemy sovremennoi informatiki [Philosophy of information and fundamental problems of modern Informatics]. Alma mater (High School Herald), (1), 29-35.

20. Mashchenko M.V. (2011). Formirovanie konkurentosposobnosti uchitelia informatiki v protsesse professional'noi podgotovki [Formation of the IT teacher's competitiveness in the process of professional training]. Vestnik of Orel State University. Series: New humanitarian research, 2 (16), 113-117.

21. Proekt Strategii EEK OON dlia obrazovaniia v interesakh ustoichivogo razvitiia [The project of the UNECE strategy for education in the interests of sustainable development]. Obrazovanie dlia ustoichivogo razvitiia. Materialy seminara "Ekologicheskoe obrazovanie $i$ obrazovanie dlia ustoichivogo razvitiia (Education for sustainable development. Proceedings of the seminar "Environmental education and education for sustainable development"). Ed. by N.S. Kasimov. Moscow, Smolensk, 2004. Pp. 9-10.

22. Robert I.V. Sovremennye informatsionnye tekhnologii v obrazovanii: didakticheskie problem; perspektivy ispol'zovaniia [Modern information technologies in education: didactic problems; prospects of implementation]. Moscow: IIO RAO, 2010. 140 p.

23. Shvartsman K.A. Filosofiia $i$ vospitanie: kriticheskii analiz nemarksistskikh kontseptsii [Philosophy and education: critical analysis of non-Marxist conceptions]. Moscow: Politizdat, 1989. $208 \mathrm{p}$.

24. Sokiev Kh.V. (2013). Osnovy razvitiia chelovecheskogo faktora v informatizatsii obshchestva $i$ informatsionnaia deiatel'nost' cheloveka [The basics of a human factor development in the information society and a human's information activities]. Credo new, (2). Available at: http://credonew.ru /content/ view/1221/68/

25. Sud nad sistemoi obrazovaniia: strategiia na budushchee [The education system trial: a strategy for the future]. Ed. by W.D. Johnston. Moscow: Pedagogika, 1991. 260 p.

26. Toffler E. Shok budushchego [Shock of the future]. Moscow: Publishing House "AST", 2002. $557 \mathrm{p}$.

27. Toffler O. Tret'ia volna [The third wave]. Moscow: Publishing house "AST", 2010. 784 p.

28. Ursul A.D. (1993). Informatizatsiia obshchestva i perekhod $\mathrm{k}$ ustoichivomu razvitiiu tsivilizatsii [Informatization of society and transition to sustainable development of civilization. Vestnik ROIVT, $(1-2), 35-45$.

29. Ursul A.D. Model' operezhaiushchego obrazovaniia: noosferno-ekologicheskii rakurs [Model of advanced / anticipatory education: noosphere-and-ecological perspective]. Filosofskie problemy obrazovaniia: sbornik statei (Philosophical problems of education: Collection of articles). Moscow: Publishing House of the Russian Academy of Public Service, 1996. Pp. 182-204.

30. Ursul A.D. (1997). Stanovlenie informatsionnogo obshchestva i model' operezhaiushchego obrazovaniia [Development of an information society and a model of advanced education]. Nauchnotekhnicheskaia informatsiia. Seriia 1, (2), 1-11.

31. Ursul A.D. Perekhod Rossii $k$ ustoichivomu razvitiiu. Noosfernaia strategiia [Transition of Russia to sustainable development. Noosphere strategy]. Moscow: Publishing house "Noosphere", 1998. 
32. Ursul A.D. (2001). Model' obrazovaniia XXI veka: problemy ustoichivosti ravitiia i bezopasnosti [Model of education in the XXI century: problems of sustainable development and security]. Bezopasnost' Evrazii, (4), 61-96.

33. Ursul A.D., Ursul T.A. Universal'nyi evoliutsionism (kontseptsii, podkhody, printsipy, perspektivy) [Universal evolutionism (conceptions, approaches, principles, prospects]. Moscow, 2007. $326 \mathrm{p}$.

34. Ursul A.D. (2010). Obrazovanie v informatsionno-evoliutsionnom rakurse [Education in information and evolutionary perspective]. Open education, (6), 89-97.

35. Ursul A.D., Ursul T.A. Megatrendy evoliutsii obrazovaniia tret'ego tysiacheletiia [Megatrends of the education evolution in the third millennium]. Obraz cheloveka budushchego: Kogo i kak vospityvat'v podrastaiushchikh pokoleniiakh (Image of a man of the future: Whom and how to educate in younger generation Bazaluk). Ed. by O.A. Bazaliuk. Kiev, 2013. Pp. 39-95.

36. Vazina K.Ia., Kopeikina E.Iu. Upravlenie innovatsionnymi protsessami v sisteme obrazovaniia (kontseptsiia, opyt) [Management of innovative processes in the education system (conception, practice). Nizhny Novgorod, 1999. $155 \mathrm{p}$.

37. Vul'fson B.L. Strategiia razvitiia obrazovaniia na Zapade na poroge XXI veka [The strategy of education development in the West on the threshold of the XXI century]. Moscow: URAO, 1999. 204 p.

38. Vygotsky L.S. Pedagogicheskaia psikhologiia [Pedagogical psychology]. Moscow: Pedagogika, 1991. 480 p.

\section{Образование в информационном обществе:}

\section{тенденция к виртуализации}

И.Г. Борисенко

Сибирский федеральный университет Россия, 660041, Красноярск, пр. Свободный, 79

Статья посвящена анализу тенденций, которые являются следствием процессов информатизации, их неоднозначности при переходе к информационному обществу. Авторы подчеркивают, что информатизачия образования влечет за собой радикальные изменения в системе образования, сопровождаются изменением традичионных методов учебного познания в вузе. В статье, в частности, показано, что амбивалентные тенденции, характеризующие процессы информатизации в образовательной системе, часто приводят к виртуализации соииальных связей.

Для понимания сущности процесса виртуализащии образования в глобальном мире важно учитывать, что образовательная система определяется как совокупность факторов, определяющих обучение и развитие личности, социокультурные и экономические условия общества, влияющие на образование, характер информационных и межличностных отношений, взаимодействия с сочиальной средой. Поскольку зависимость межличностных отношений и взаимодействия образования с социальной средой очевидна, то есть в любом случае факторы и условия, определяющие обучение и развитие личности, не только привносятся из внешней по отношению к образованию сочиально-экономической среды, но и создаются самим образовательным прочессом, являются продуктом информачионно-образовательного взаимодействия, межличностных отношений субъектов образования. 
Виртуализация образовательных процессов современности во многом связана с тем фактом, что информационный характер системы образования создает предпосылки для универсализации средств и ресурсов межпредметных связей. Через общую образовательную среду различные гуманитарные и естественнонаучные предметы интегрируются, что предполагает поиск источников межпредметных связей и средств их реализации, используя авторские средства, методы и формы. Целью этого процесса является формирование у студентов системного научного мышления, экологической и информационной культуры, творческой активности и высокой нравственности - качеств, которые позволят им успешно адаптироваться, жить и работать в глобальном информационном обществе.

Виртуализация образовательного пространства видоизменяет роль преподавателя, однако не отрицает значимости традиционных субъект-объектных отношений в образовательном nроиессе.

Особую роль в этом плане, согласно статье, играют смарт-технологии. Несмотря на тенденциию $к$ виртуализации, современное образовательное пространство базируется не только на новейших информацчионых технологиях, но и на использовании традиционных авторских образовательных методик. Благодаря умелому сочетанию традиционных и информационных подходов образовательный процесс сохраняет свою эффективность.

Ключевые слова: информационное общество, информационное образование, глобальное образование, проблемы образования, информация, информатика.

Научная специальность: 09.00.00-философские науки. 